\title{
Implementation of a Hidden Markov Model in a photoreceptor cell by the biochemical mechanisms of phototransduction Audrey Houillon*1, Pierre Bessière ${ }^{2}$ and Jacques Droulez ${ }^{1}$
}

\author{
Address: ${ }^{1}$ Laboratoire de Physiologie de la Perception et de l'Action-CNRS/Collège de France, Paris, 75015, France and ${ }^{2}$ Laboratoire d'Informatique \\ de Grenoble-CNRS/Grenoble Universités, Grenoble, 38041, France \\ Email: Audrey Houillon* - audrey.houillon@college-de-france.fr \\ * Corresponding author
}

from Eighteenth Annual Computational Neuroscience Meeting: CNS*2009

Berlin, Germany. 18-23 July 2009

Published: 13 July 2009

BMC Neuroscience 2009, 10(SuppI I):P46 doi:10.I I86/I47I-2202-I0-SI-P46

This abstract is available from: http://www.biomedcentral.com//47I-2202/I0/SI/P46

(c) 2009 Houillon et al; licensee BioMed Central Ltd.

\section{Introduction}

Probabilistic perceptive and behavioral models have received a growing interest lately, as they account for the ability to reason with incomplete knowledge about the external world. In this study, we consider how the probability distributions that need to be estimated in these models could be represented and processed at the single cell level by the underlying biochemical mechanisms, in particular in a photoreceptor cell. We consider how the molecular interactions in a photoreceptor cell can compute a probabilistic inference in the case of a binary Hidden Markov Model (HMM). The HMM is of interest since it is one of the simplest form of time-dependent probabilistic models, and is widely used in cognitive probabilistic modeling, as the base for more complex models. We show that the cell estimates the current state probability distribution by means of the biochemical mechanisms of phototransduction.

The interactions between the different molecular messengers, ions, enzymes and channel proteins within the photoreceptor cell are described by a set of nonlinear coupled differential equations [1], whereas the HMM is described by a discrete recurrence equation. In the first model, we derived, under steady-state conditions, a formal equivalence between the HMM inference and some of the biochemical mechanisms involved in phototransduction. We can then point out the similarity of the solutions and find the relations between the parameters of both systems if the intracellular calcium concentration encodes the posterior probability ratio. We performed numerical simulations to extend the results to the dynamic case. We then derived a second model under the more general case of a constant input, under which conditions we find a general solution for the binary HMM, as well as for the biochemical system. As in the first model, we can find new relations between both systems and simulate the dynamic case.

\section{Results}

For both models we compared the temporal evolution of the intracellular calcium concentration with the posterior probability ratio inferred by the HMM. For the dynamical case, we considered different time-varying light intensities as the input. We finally compared the performance of both models.

\section{Discussion}

We have showed how simple biochemical interactions can implement simple probabilistic reasoning. Furthermore, we discuss the possibility to extend the temporal calcium concentration to a spatio-temporal variable by involving the cell structure and diffusion mechanisms and how it could permit us to enhance the probabilistic models to a continuous state variable. 


\section{Acknowledgements}

We thank the support of the European Community Project BACS (FP6-

IST-027I40).

\section{References}

I. Nikonov S, Lamb TD, Pugh EN Jr: The role of steady phosphodiesterase actvity in the kinetics of the light-adapted salamander rod photoresponse. J Gen Physiol 2000, I 1 6:795-824.

Publish with Bio Med Central and every scientist can read your work free of charge

"BioMed Central will be the most significant development for disseminating the results of biomedical research in our lifetime. " Sir Paul Nurse, Cancer Research UK

Your research papers will be:

- available free of charge to the entire biomedical community

- peer reviewed and published immediately upon acceptance

- cited in PubMed and archived on PubMed Central

- yours - you keep the copyright

Submit your manuscript here:

http://www.biomedcentral.com/info/publishing_adv.asp 